\title{
Daya Saing Lulusan Manajemen Pendidikan
}

\author{
Rahmanto Samina $^{1}$,Ansar ${ }^{2}$, Arwildayanto ${ }^{3}$ \\ Jurusan Manajemen Pendidikan Fakultas Ilmu Pendidikan \\ Universitas Negeri Gorontalo \\ E-mail: saminarahmanto@gmail.com
}

\begin{abstract}
INFO ARTIKEL ABSTRAK
Sejarah Artikel:

Diterima: Januari 2020

Disetujui: Februari 2020

Dipublikasi: Maret 2020

\section{Kata kunci:}

Alumni; daya saing;

pekerjaan

Keywords:

graduate;

competitiveness;

Penelitian ini bertujuan untuk mengetahui daya saing lulusan Manajemen Pendidikan Fakultas Ilmu Pendidikan Universitas Negeri Gorontalo dalam masa tunggu untuk mendapatkan pekerjaan, kesesuaian bidang kerja dengan keahlian dan partisipasi alumni dalam mendukung kemajuan program studi. Penelitian ini menggunakan pendekatan kuantitatif dengan jenis penelitian deskriptif eksplanatori. Jumlah populasi penelitian yaitu 268 orang dan sampel sampel penelitian yaitu 61 orang. Teknik pengumpulan data menggunakan kuisioner, wawancara, observasi dan dokumentasi. Adapun hasil dari penelitian ini menunjukan bahwa : 1) formasi kerja alumni berada pada kategori cukup tersedia, 2) keseuaian bidang kerja dengan keahlian artinya berada pada kategoti sesuai, 3) partisipasi alumni dalam mendukung kemajuan program studi berada pada kategori cukup sesuai.
\end{abstract}

profession

\section{ABSTRACT}

This study aims to determine the competitiveness of Educational Management graduates of the Faculty of Education at the State University of Gorontalo in the waiting period to get a job, suitability of the work field with expertise and alumni participation in supporting the progress of the study program. This study uses a quantitative approach to the type of descriptive explanatory research. The total population of the study was 268 people and the sample of the study sample was 61 people. Data collection techniques using questionnaires, interviews, observation and documentation. The results of this study indicate that: 1) the formation ofgraduate work it is in the sufficiently available category, 2) the suitability of the work field with expertise meanthat it is in the appropriate category, 3) graduate participation in supporting progress the study program mean that it is in the quiteappropriate category.

(C) 2020 Rahmanto Samina, Ansar, Arwildayanto Under The License CC BY-SA 4.0

\section{PENDAHULUAN}

Persaingan merupakan ciri utama peradaban modern telah berkembang seiring mantapnya pemahaman terhadap teknologi informasi dan komunikasi yang inovatif dan variatif. Duniapendidikan harus terlibat dalam persaingan ini. Tidak terkecuali institusi pendidikan tinggi dituntut untuk menunjukkan profesionalitas dalam pemberian layanan akademisnya. Tingginya tingkat persaingan di level pendidikan tinggi ini menyebabkan lembaga pendidikan tinggi harus bersiap diri, menganalisis daya saingnya dan menerapkan 
strategi untuk mencari keunggulan agar bisa menjamin terjaganya eksistensi institusi pendidikan tinggi dalam persaingan yang semakin ketat (Hamid,2011).

Daya saing merupakan efisiensi dan efektivitas yang memiliki sasaran yang tepat dalam menentukan tujuan dan hasil sasaran yang ingin dicapai yang meliputi tujuan akhir dan proses pencapaian akhir dalam menghadapai persaingan. Sumihardjo (2008: 8), memberikan penjelasan tentang istilah daya saing ini, yaitu kata daya pada kalimat daya saing bermakna kekuatan, dan kata saing artinya mencapai lebih dari yang lain,atau beda dengan yang lain dari segi mutu, atau memiliki keunggulan tertentu. Artinya daya saing bisa bermakna kekuatan untuk berusaha menjadi lebih dari yang lain dan unggul dalam hal tertentu baik yang dilakukan individu, kelompok maupun institusi tertentu. Selanjutnya (Sumihardjo, 2008: 11), mengemukakan bahwa "daya saing meliputi: (1) kemampuan memperkokoh posisi pasarnya, (2) kemampuan menghubungkan dengan lingkungannya, (3) kemampuan meningkatkan kinerja tanpa henti, dan (4) kemampuan menegakkan posisi yang menguntungkan".

Menurut Menteri Pendidikan Nasional mendefinisikan daya saing adalah kemampuan untuk menunjukkan hasil yang lebih baik, lebih cepat atau lebih bermakna. Kemampuan yang dimaksud adalah (1) kemampuan memperkokoh pangsa pasarnya, (2) kemampuan menghubungkan dengan lingkungannya, (3) kemampuan meningkatkan kinerja tanpa henti, (4) kemampuan menegakkan posisi yang menguntungkan. Sementara itu menurut (Harald Schomburg, 2003:11) menjelaskan tracer study merupakan pendekatan yang membuat institusi pendidikan mendapatkan informasi mengenai permasalahan yang terjadi pada proses pendidikan dan proses pembelajaran dan dapat dijadikan dasar untuk perencanaan kegiatan dalam perbaikan dimasa mendatang. Menurut (Daniel Rivai, 2009) bahwa pada hasil tracer study diketahui bahwa waktu tunggu yang relatif lama antara lain disebabkan oleh beberapa faktor, dua hal yang terpenting adalah kualitas soft-skill lulusan yang kurang memadai dan meningkatnya tingkat persaingan antar pencari kerja yang memiliki kompetensi keahlian/bidang ilmu yang sama.

Dari beberapa penjelasan diatas, dapat disimpulkan bahwa tracer study sangat diperlukan agar institusi pendidikan dapat meningkatkan kesuksesan dalam mempersiapkan para alumninya memasuki dunia kerja baik dilembaga pendidikan maupun dunia usaha/industry. Perguruan tinggi sangatbergantungpadaalumni,karena alumni dapat memberikan feedback terhadap kemajuan perguruan tinggi tersebut melalui persepsi masyarakat terhadap keberadaan alumninya di tengah-tengah masyarakat, khususnya 
keberadaannya di duniakerja.

Dari pendapat di atas dapat disimpulkan bahwa daya saing adalah kemampuan dari seseorang/kelompok untuk menunjukkan keunggulan dalam bidang tertentu, dengan cara memperlihatkan situasi dan kondisi yang paling menguntungkan, hasil kerja yang lebih baik, lebih cepat atau lebih bermakna dibandingkan dengan yang lainnya. Menurut (Djuwariyah, 2008:16) perguruan tinggi mempunyai peran ganda yaitu: (1) Pendidikan memiliki tugas untuk membina kemanusiaan (human being), berarti tujuan pendidikan yaitu untuk mengembangkan pribadi manusia, termasuk mempersiapkan manusia sebagai anggota masyarakat, rasa persatuan dan warga negara yang baik; (2) Pendidikan memiliki fungsi sebagai pengembangan sumber daya manusia (human resources), yaitu meningkatkan kualitas untuk menuju era kehidupan yang baru. Tracer study merupakan salah satu kegiatan yang dilakukan perguruan tinggi untuk mengikuti perkembangan lulusan atau alumni. Tracer study bertujuan untuk mengetahui outcome pendidikan selama transisi dari dunia perguruan tinggi ke dunia kerja, output pendidikan yaitu penilaian diri terhadap penguasaan dan pemerolehan kompetisi, proses pendidikan berupa evaluasi proses pembelajaran dan kontribusi perguruan tinggi terhadap pemeroleh kompetisi, input pendidikan berupa penggalian lebih lanjut terhadap informasi sosiobiografis lulusan (Arwildayanto, 2012).

Daya saing merupakan salah satu keunggulan yang sangat penting dalam sebuah organisasi. Daya saing perguruan tinggi yang dimaksud disini tidak hanya sebuah kekuatan tapilebih dari itu merupakan konsistensi untuk tetap bertahan menghadapi persaingan yang semakin ketat. Kemampuan tersebut adalah (1) kemampuan memperkokoh pangsa pasarnya, (2) kemampuan menghubungkan dengan lingkungan, (3) kemampuan meningkatkan kinerja tanpa henti, (4) kemampuan memperoleh posisi yang menguntungkan (Sumihardjo, 2008). Persaingan pendidikan menjadi salah satu indikator yang menunjukan kualitas sumber daya manusia yang ada dalam lembaga pendidikan tinggi tersebut.Baikdarikualitasmahasiswa, dosen ataupun tenaga pendidikanyang berkecimpu dalam lembagatersebut.

Berdasarkan hasil observasi awal pada tanggal 11 Februari 2019 diFakultas Ilmu Pendidikan yang merupakan salah satu fakultas tertua yang ada di Universitas Negeri Gorontalo (UNG) dimana saat ini Fakultas Ilmu Pendidikan mengelola lima jurusan dalam bidang pendidikan yaitu: Manajemen Pendidikan, Bimbingan dan Konseling,Pendidikan Guru Sekolah Dasar, Pendidikan Guru Pendidikan Anak Usia Dini, dan Pendidiksn LuarSekolah. 
Dalam menghadapi ketatnya persaingan pada dunia pendidikan, Dekan Fakultas Ilmu Pendidikan sudah mengeluarkan surat keputusanNomor: 568/UN47.B1/DT/2015 tentang Budaya Kerja Champion dosen dan tenaga kependidikan. Adapun makna champion antara lain (1) Competitiveness yaitu individu yang produktif menggunakan potensi yang dimiliki dan menghasilkan lulusan yang berdaya saing tinggi (2) Honour yaitu melayani dengan maksimal/prima dan menjaga kehormatan profesi (3) Achivement Orientation yaitu orientasi kerja dengan standar prestasi dan terus menerus meraih keunggulan (4) Morality yaitu sifat, karakter dan perilaku kerja bersumber dari nilai agama, moralitas, norma, etika profesi sebagai kompas dalam mendidik (5) Pioneering yaitu kesukarelawan diri atas tanggung jawab sosial, menciptakan sesuatu/mengubah gagasan menjadi karya nyata (6) Innovation yaitu meningkatkan cara kerja, membuatnya lebih mudah, lebih baik dan lebih cepat serta selalu menciptakan sesuatu yang baru (7) Optimism yaitu bekerja dengan keyakinan tinggi bisa menyelesaikan dengan hasil terbaik dan (8) Nationalism yaitu bekerja mewujudkan tujuan negarauntuk mencerdaskan anak bangsa, menjaga dan mempertahankan keutuhan Negara Kesatuan Republik Indonesia (Arwildayanto, 2016).

Program studi Manajemen Pendidikan merupakan salah satu jurusan yang ada di Fakultas Ilmu Pendidikan. Dalam upaya meningkatkan daya saing lulusan, program studi Manajemen Pendidikan memiliki visi bahwa pada tahun 2025 program studi Manajemen Pendidikan menjadi pusat pengembangan keilmuan yang menghasilkan lulusan berkarakter tangguh, inovatif dan kompetitif yang diakui secara global. Dalam usaha meningkatkan daya saing tidak terlepas dari peran kinerja dosen dalam memberikan pelayanan terhadap mahasiswa yang ada di lingkungan jurusan Manajemen Pendidikan. Dosen harus bisa menghasilkan mahasiswa yang handal dalam dunia persaingan sehingga dapat meningkatkan image atau pencitraan positif terhadap program studi Manajemen Pendidikan. Peningkatan kualitas pendidikan tentu tidak lepas dari proses peningkatan kualitas sumber daya manusia.

Dengan menyadari pentingnya proses peningkatan sumber daya manusia, maka pemerintah bersama lembaga pendidikan terus berupaya mewujudkan amanat tersebut dengan berbagai usaha pembangunan pendidikan yang lebih berkualitas antara lain melalui pengembangan dan perbaikan kurikulum dan sistem evaluasi, perbaikan sarana pendidikan, pengembangan dan pengadaan materi ajar, serta pelatihan dosen dan tenaga kependidikan lainnya. Program studi Manajemen Pendidikan sudah menghasilkan lulusan-lulusan mahasiswa disetiap tahunnya, akan tetapi kompetisi mahasiswa khususnya alumni masih banyak yang belum menduduki jabatan-jabatan penting pada institut tertentu yang ada di 
Provinsi Gorontalo maupun diluar Provinsi Gorontalo dan masih banyak terdapat alumni yang belum mendapatkan pekerjaan dan bahkan harus menunggu dengan rentan waktu yang cukup lama untuk mendapatkan pekerjaan yang sesuai dengan keahlian mereka masingmasing. Oleh karena itu dibutuhkan langkah-langkah konkrit untuk membuat programprogram dalam mengatasi hal tersebut sehingga lulusan Manajemen Pendidikan bisa bersaing dari segi kompetensi dan prestasi yang dimiliki Mahasiswa lulusan Manajemen Pendidikan Fakultas Ilmu Pendidikan UNG.

Berdasarkan latar belakang masalah diatas maka tujuan penelitian ini adalah: (1) Untuk mengetahui daya saing lulusan Manajemen Pendidikan dilihat dari formasi kerja, (2) Untuk mengetahui kesesuaian bidang pekerjaan alumni Manajemen Pendidikan dengan keahlian, (3) Untuk mengetahui partisipasi alumni Manajemen Pendidikan dalam mendukung kemajuan program studi.

\section{METODE PENELITIAN}

Metode yang digunakan dalam penelitian adalah penelitian kuantitatif dengan jenis penelitian deskriptif eksplanatori. Indikator pada penelitian ini yaitu (1) formasi kerja alumni, (2) kesesuaian bidang pekerjaan dengan keahlian alumni, (3) partisipasi alumni dalam mendukung kemajuaan program studi. Populasi dalam penelitian ini adalah lumni Manajemen Pendidikan lulusan tahun 2016-2018 dengan jumlah 268 orang. Adapun teknik pengambilan sampel yakni menggunakan teknik Insidental Sampling dan diperoleh sampel sebanyak 61 orang. Teknik pengumpulan data dalam penelitian ini menggunakan observasi, angket, wawancara dan dokumentasi. Jenis angket penelitian ini adalah angket tertutup dengan menggunakan skala likert yaitu sangat sesuai/sangat tersedia, sesuai/tersedia, cukup sesuai/cukup tersedia, tidak sesuai/tidak tersedia dan sangat tidak sesuai/sangat tidak tersedia.

\section{HASILPENELITIAN}

Berdasarkan penelitian diatas, diperoleh hasilpenelitian sebagai berikut:

1. Indikator Formasi Kerja

Berdasarkan indikator diatas terbagi menjadi enam pernyataan yaitu: 1) kemudahan mendapatkan pekerjaan, 2) persaingan dalam mencari pekerjaan, 3) kesesuaian dengan kebutuhan tenaga kerja, 4) memiliki pekerjaan yang menetap, 5) tersedianya lowongan kerja sesuai keahlian, 6) kriteria penerimaan tenaga kerja tinggi.Berikut uraian dalam bentuk tabel dan kesimpulan hasil penelitian : 
Tabel 1. Rangkuman Skor Indikator Formasi Kerja Alumni

\begin{tabular}{|c|c|c|c|c|}
\hline No. & Pernyataan & Skor & Presentase & Kriteria \\
\hline 1 & Kemudahan mendapatkan pekerjaan & 222 & 72.78 & Cukup Tersedia \\
\hline 2 & Persaingan dalam mencari pekerjaan & 245 & 80.32 & Cukup Tersedia \\
\hline 3 & $\begin{array}{l}\text { Kesesuaian dengan kebutuhan tenaga } \\
\text { kerja }\end{array}$ & 236 & 77.37 & Cukup Sesuai \\
\hline 4 & Memiliki pekerjaan yang menetap & 218 & 71.47 & Cukup Tersedia \\
\hline 5 & $\begin{array}{l}\text { Tersedianya lowongan kerja sesuai } \\
\text { keahlian }\end{array}$ & 205 & 67.21 & Tidak Tersedia \\
\hline \multirow[t]{2}{*}{6} & $\begin{array}{l}\text { Kriteria penerimaan tenaga kerja } \\
\text { tinggi }\end{array}$ & 218 & 71.47 & Cukup Tersedia \\
\hline & Rata-rata & 224 & 73.44 & Cukup Tersedia \\
\hline
\end{tabular}

Dalam hasil penelitianIndikator formasi kerja memiliki presentase $73.44 \%$ dengan kriteria cukup tersdiadenganjumlahresponden yaitu 60 orang, ada 37responden yang bekerja sesuai ruang lingkup Manajemen Pendidikan,13responden yang bekerja diluarruanglingkup Manajemen Pendidikan dan 11 responden yang belum memilki pekerjaan. Kedua,kurangnyakemauan dari alumni untuk berusaha mendapatkan pekerjaanyangsesuai. Ketiga, kurangnyalapanganpekerjaan yang sesuai dengan keahlian,danyang keempat yaitukurangnyaketeampilan atau kualitas alumnisehinggakalah bersaing dengan laumnidarijurusan lain.

2. Indikator Kesesuaian Bidang Pekerjaan dengan Keahlian

Hasil penelitianindikator kesesuaian bidang pekerjaan dengan keahlian terbagi dalam beberapa pernyataandianalisis dalam tabel dalam tabel presentase dan kesimpulan dibawah ini:

Tabel 2. Rangkuman skor indikator kesesuaian bidang pekerjaan dengan keahlian

\begin{tabular}{llccc}
\hline No & \multicolumn{1}{c}{ Pernyataan } & Skor & Presentase & Kriteria \\
\hline 1 & Pencapaian dalam berprestasi rendah & 240 & 78.68 & Cukup Sesuai \\
2 & $\begin{array}{l}\text { Mampu bekerja sesuai dengan } \\
\text { pengetahuan dibidang ilmunya }\end{array}$ & 261 & 85.57 & Sesuai \\
3 & $\begin{array}{l}\text { Mampu menyesuaikan bidang ahli } \\
\text { dengan kebutuhan instansi }\end{array}$ & 850 & 85.24 & Sesuai \\
4 & $\begin{array}{l}\text { Memiliki pengetahuan diluar bidang } \\
\text { ahli }\end{array}$ & 246 & 80.65 & Cukup Sesuai \\
\hline
\end{tabular}




\begin{tabular}{|c|c|c|c|c|}
\hline 5 & $\begin{array}{l}\text { Memiliki pengetahuan sesuai disiplin } \\
\text { ilmu alumni }\end{array}$ & 260 & 85.24 & Sangat Sesuai \\
\hline 6 & Memiliki etos kerja rendah & 250 & 81.96 & Sesuai \\
\hline 7 & $\begin{array}{l}\text { Memiliki inisiatif-inisiatif yang bisa } \\
\text { dikembangkan }\end{array}$ & 228 & 74.75 & Cukup Sesuai \\
\hline 8 & $\begin{array}{l}\text { Kemampuan dalam bekerja secara } \\
\text { mandiri }\end{array}$ & 262 & 85.90 & Sesuai \\
\hline 9 & $\begin{array}{l}\text { Mampumenggunakan pengetahuaannya } \\
\text { sesuai dengan keahliannya }\end{array}$ & 264 & 86.55 & Sesuai \\
\hline 10 & $\begin{array}{l}\text { Kemampuan dalam menyesuaikan } \\
\text { bidang keahlian dengan pekerjaan yang } \\
\text { tersedia }\end{array}$ & 226 & 74.09 & Cukup Sesuai \\
\hline 11 & $\begin{array}{l}\text { Memiliki keahlian dalam hubungan } \\
\text { interpersonal }\end{array}$ & 244 & 80.00 & Cukup Sesuai \\
\hline 12 & $\begin{array}{l}\text { Kemampuan dalam mempresentasikan } \\
\text { ide/produk/laporan }\end{array}$ & 252 & 82.62 & Sesuai \\
\hline 13 & $\begin{array}{l}\text { Memiliki kemampuan dalam menulis } \\
\text { laporan, memo, dan dokumentasi } \\
\text { pekerjaan }\end{array}$ & 244 & 80.00 & Cukup Sesuai \\
\hline 14 & $\begin{array}{l}\text { Kemampuan dalam mempersiapkan } \\
\text { laporan dan penulisan efektif }\end{array}$ & 249 & 81.63 & Sesuai \\
\hline 15 & $\begin{array}{l}\text { Kemampuan untuk berinteraksi secara } \\
\text { efektif dengan rekan sekerja }\end{array}$ & 248 & 81.31 & Sesuai \\
\hline 16 & $\begin{array}{l}\text { Keterampilan dalam memecahkan } \\
\text { masalah rendah }\end{array}$ & 250 & 81.96 & Sesuai \\
\hline 17 & $\begin{array}{l}\text { Keterampilan dalam melaksanakan } \\
\text { tugas }\end{array}$ & 261 & 85.57 & Sesuai \\
\hline 18 & Kemampuan dalam berpikir kritis & 248 & 81.63 & Sesuai \\
\hline 19 & $\begin{array}{l}\text { Kemampuan dalam mengembangkan } \\
\text { alternative }\end{array}$ & 243 & 79.67 & Cukup Sesuai \\
\hline \multirow[t]{2}{*}{20} & $\begin{array}{l}\text { Kemampuan dalam menganalisis suatu } \\
\text { masalah }\end{array}$ & 236 & 77.37 & Cukup Sesuai \\
\hline & Rata-rata & 248.6 & 81.51 & Sesuai \\
\hline
\end{tabular}

Hal ini menunjukan rangkuman skor pada indikator kesesuaian bidang pekerjaan dengan keahlian. Dari sejumlah pernyataan yang dijadikan instrumen pada indikator ini diperoleh hasil yaitu berada pada kategori Sesuai dengan presentase $81.51 \%$. Sehingga pada seluruh indikator ini perlu dipertahankan dan ditingkatkan lagi untuk menghasilkan lulusan Manajemen Pendidikan yang berkualitas. 
3. Indikator Partisipasi Alumni dalam Mendukung Kemajuan Program Studi

Dari hasil penelitian indikator partisipasi alumni dalam mendukung kemajuan program studi memiliki presentase $77.88 \%$ dengan kriteria Cukup Sesuai.Hasil ini mengindikasikan bahwa pada indikator ini masih perlu adanya perbaikan dan peningkatan, baik yang dilakukan oleh pihak jurusan maupun mahasiswa atau alumni. Alumni memiliki peran yang sangat penting dalam mendukung kemajuan program studi.

Rekapitulasi seluruh hasil penelitian yang diperoleh dalam daya saing lulusan manajemen pendidikan berada pada presentase $77.61 \%$ dengan kriteria Cukup Sesuai. Oleh karena itu, pihak jurusan harus mempertahankan dan mempunyai rancangan strategi untuk meningkatkan kualitas lulusan Manajemen Pendidikan Fakultas Ilmu Pendidikan Universitas Negeri Gorontalo. Rangkuman hasil penelitian dapat dilihat pada table dibawah ini:

Tabel 3. Rangkuman skor indikator partisipasi alumni dalam mendukung kemajuan program studi

\begin{tabular}{llcccc}
\hline No. & \multicolumn{1}{c}{ Pernyataan } & Skor & Presentase & Kriteria \\
\hline 1 & $\begin{array}{l}\text { Berpartisipasi dalam pengembangan } \\
\text { program studi }\end{array}$ & 239 & 78.36 & Cukup Sesuai \\
2 & $\begin{array}{l}\text { Kurang berpartisipasi dalam kegiatan } \\
\text { akademik }\end{array}$ & 239 & 78.36 & Cukup Sesuai \\
3 & $\begin{array}{l}\text { Berpartisipasi dalam kegiatan non } \\
\text { akademik } \\
\text { Memperkenalkan program studi pada } \\
\text { masyarakat }\end{array}$ & 231 & 75.73 & Cukup Sesuai \\
5 & $\begin{array}{l}\text { Bekerja sama dengan program studi } \\
\text { dalam bertukar informasi tentang }\end{array}$ & 225 & 73.77 & Cukup Sesuai \\
$\begin{array}{l}\text { lapangan pekerjaan } \\
\text { Memiliki kepuasan selama proses } \\
\text { perkuliahan } \\
\text { Memiliki kepuasan selama bimbingan } \\
\text { karya tulis ilmiah (Skripsi) } \\
\text { Memiliki kepuasan dalam ketersediaan } \\
\text { sarana dan prasarana }\end{array}$ & 250 & 81.96 & 207 \\
$\begin{array}{l}\text { Kurang puas dengan kurikulum } \\
\text { program studi }\end{array}$ & 242 & 79.34 & Cukup Sesuai \\
\hline \hline
\end{tabular}


Hasil rekapitulasi keseluruhan indikator daya saing lulusan Manajemen Pendidikan dapat dilhat pada table di bawah:

Tabel 4. Rangkuman Keseluruhan Skor Indikator

\begin{tabular}{|c|l|c|c|c|}
\hline $\begin{array}{c}\text { No } \\
\text { Tabel }\end{array}$ & \multicolumn{1}{|c|}{ Indikator } & Skor & $\begin{array}{c}\text { Presentase } \\
(\%)\end{array}$ & Kriteria \\
\hline 1 & Formasi Kerja Alumni & 224 & 73.44 & $\begin{array}{c}\text { Cukup } \\
\text { Tersedia }\end{array}$ \\
\hline 2 & $\begin{array}{l}\text { Kesesuaian Bidang Pekerjaan dengan } \\
\text { Keahlian }\end{array}$ & 248.6 & 81.51 & Sesuai \\
\hline 3 & $\begin{array}{l}\text { Partisipasi Alumni Dalam Mendukung } \\
\text { Kemajuan Program Studi }\end{array}$ & 237.55 & 77.88 & Cukup Sesuai \\
\hline & Rata-Rata & 236.71 & 77.61 & Cukup Sesuai \\
\hline
\end{tabular}

Rekapitulasi variabel analisis daya saing lulusan manajemen pendidikan menunjukan bahwa indikator formasi kerja alumni berada pada kriteria Cukup Tersedia dengan presentase $73.44 \%$, kesesuaian bidang pekerjaan dengan keahlian berda pada kriteria Sesuai dengan presentase $81.51 \%$, dan partisipasi alumni dalam mendukung kemajuan program studi berada pada kriteria cukup sesuai dengan presentase $77.88 \%$.Berikut ini diagram analisis daya saing lulusan Manajemen Pendidikan Fakultas Ilmu Pendidikan Universitas Negeri Gorontalo:

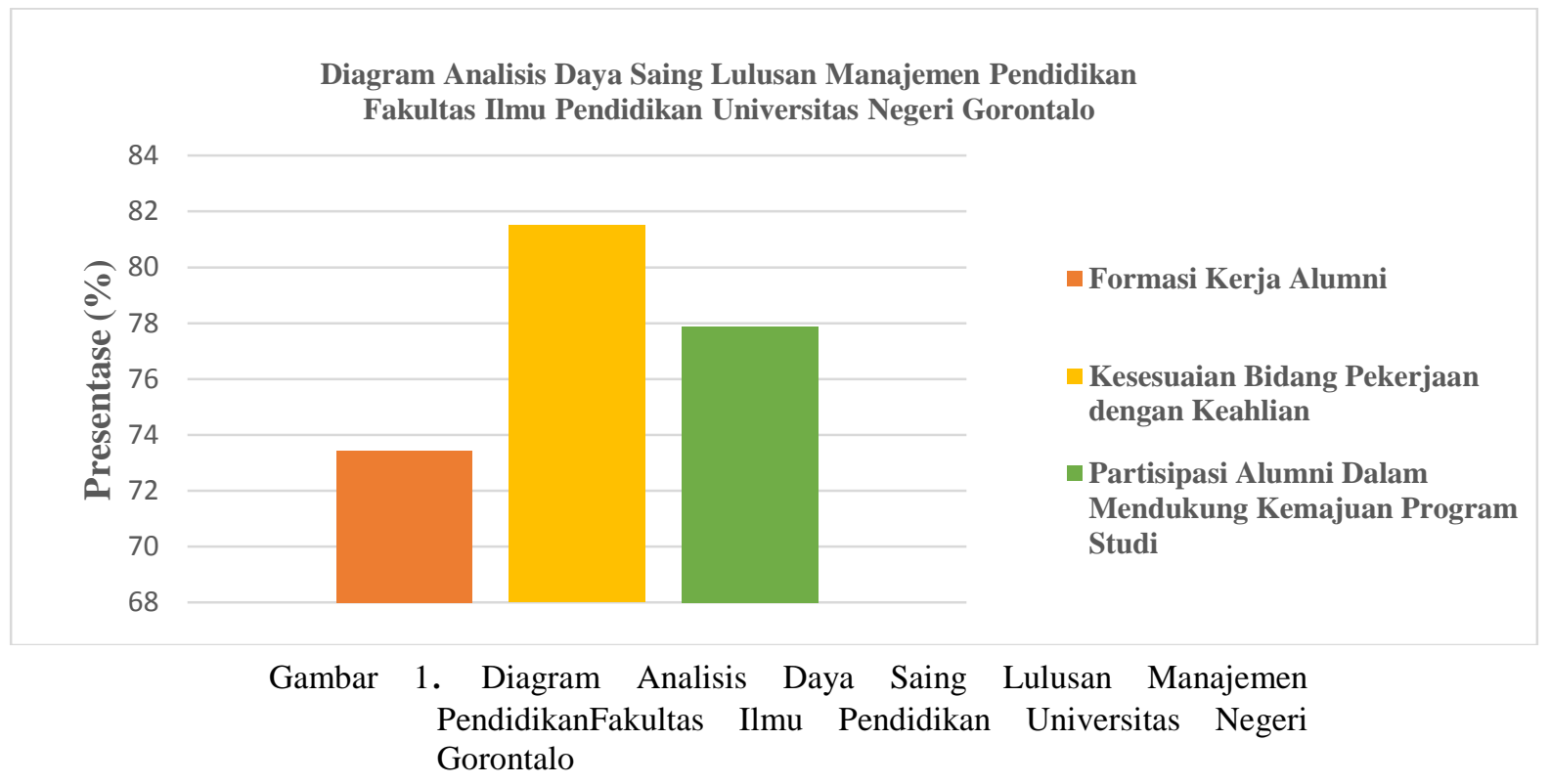

\section{PEMBAHASAN}

1. Formasi KerjaAlumni

Berkaitan dengan formasi kerja alumni, dapat diketahui indikator ini terletak pada kategori cukup tersedia dengan presentase rata-rata $73.44 \%$. Hasil ini menunjukan bahwa 
formasi kerjaalumnimasiperludiperbaikidan ditingkatkan, baik dari peningkatan kualitas lulusan, perbaikan kurikulum dan peningkatan masa tunggu lulusan. Hal ini sesuai dengan yang dikemukakan oleh (Daniel Rivai, 2009) "waktutungguyangrelatiflamaantara lain disebabkan oleh beberapa faktor, dua hal yang terpenting adalah kemampuan soft-skill lulusan yang kurang memadai dan meningkatnya tingkat persaingan antar pencari kerja yang memiliki kompetensi keahlian/ bidang ilmu yangsama.

Salah satu yang mendukung formasi kerja alumni menjadi baik adalah masa tunggu alumni untuk bekerja. Sebagai contoh sebuah hasil penelitian yang dilaksanakan pada alumni program studi Pendidikan Bioligi angkatan 2001-2018 FKIP Universitas Mataram bahwa alumni rata-rata memiliki masa tunggu paling cepat antara $0-2$ bulan untuk mendapatkan pekerjaan dan masa tunggu paling lama yaitu $1-2$ tahun. Almunmi pada jurusan tersebut sebagian besar sudah bekerja padasaat merekasedangmenyelesaikanstudiS1 mereka (Karnan, dkk.2018). Jika kita bandingkan dengan alumni jurusan manajemen pendidikan yang memiliki masa tunggu paling cepat 4 bulan untuk mendapatkan pekerjaan dan bahkan masi banyak alumni lainnya yang belum bekerja maka alumni manajemen pendidikan masih dikategorikan mengalami kesulitan dalam mendapatkanpekerjaan.Penjelasan tersebut tentu perlu dijadikan bahanpertimbanganjurusan untuk meningkatkan masa tunggu lulusan dalammendapatkanpekerjaan. Berdasarkan hasil penelitianyang berada pada kategori cukupsesuai,ada beberapa faktor yangmembuathal tersebut bisa terjadi, yangpertamajika dilihat dari indikator kesesuaian lapangan pekerjaandengankeahlian yang berada pada kategori tidak tersedia tentu ini menjadi permasalahan yangharusdicarikan solusinya bersama.

Dalam hasil penelitian denganjumlahresponden yaitu 60 orang, ada 37responden yang bekerja sesuai ruang lingkup Manajemen Pendidikan,13responden yang bekerja diluarruanglingkup Manajemen Pendidikan dan 11 responden yang belum memilki pekerjaan. Kedua,kurangnyakemauan dari alumni untuk berusaha mendapatkan pekerjaanyangsesuai. Ketiga, kurangnyalapanganpekerjaan yang sesuai dengan keahlian,danyang keempat yaitukurangnyaketeampilan atau kualitas alumnisehinggakalah bersaing dengan laumnidarijurusan lain.Sehingganyaadabeberapaalumni yang belum memiliki pekerjaanyangmenetap.Solusi dibalik ini adalah melaksanakan tracer study jurusan manajemen pendidikan dengan efektif dan efisien, karena tujuan dari tracer study adalah: (1) mengetahui hasil pendidikan dalam bentuk transisi dari duniapendidikantinggikeduniakerja,(2) mengetahui keluaran pendidikan yaitu penilaian diri terhadap penguasaan dan kompetensi dan (3) mengetahui proses pendidikan berupa evaluasi 
proses pembelajaran dan kontribusi pendidikan tinggi terhadap kompetensi serta input pendidikantahun, khususnya pengangguran dari lulusan perguruan tinggi. Oleh karena itu, para calon sarjana diwajibkan untuk lebih kreatif, inovatif, memiliki kompetensi, keterampilan kerja, dan kepribadian yang baik. Hal ini karena, lowongan yang tersedia sebenarnya yang akan menjadi kendala utama untuk seorang sarjana dalam mendapatkan pekerjaan adalah kesiapan mereka untuk bekerja.

Dari hasil penelitian ini masi memerlukan evaluasi pada beberapa indikator yang ada guna untuk perbaikan dan pemantapan profesionalisme alumni Manajemen Pendidikan dalam dunia pekerjaan. Contohnya seperti pemantapan penguasaan komputer dan berbahasa Inggris karena pengetahuan tersebut yang sering diterapkan pada dunia pekerjaan. Selain itu, alumni dapat mengembangkan pengetahuannya dengan mengikuti pelatihan-pelatihan yang dilaksanakan noleh instansi merekatersendiri.

2. Kesesuaian Bidang Pekerjaan denganKeahlian

Berkaitan dengan kesesuaian bidang pekerjaan dengan keahlian alumni, dapat diketahui bahwa indikator ini terletak pada kategori Sesuai dengan presentase rata-rata yaitu 81.51\%. Hal ini menunjukan bahwa alumni mengembangkan pekerjaan berdasarkan keahlian atau profesionalisme untukmegembangkan strategi-strategi pada instansi tempat mereka bekerja sebagaimana yang dijelaskan oleh (Sururi, 2002:2) yaitu profesionalisme menunjukan komitmen anggota suatu profesi untuk meningkatkan kemampuan profesionalnya dan terusmenerus mengembangkan strategi-straregiyang digunakannya dalam melakukan pekerjaan yang sesuai dengan profesinya. Hal ini tentu memerlukan keterampilandanketeladanandaripara alumni dalam bekerja, bahkan alumni dituntut untuk memiliki kematangan emosional dalam diri mereka. Selain itu, alumni manajemen pendidikan harusmenguasaikeahlianyangmereka dapatkan pada saat perkuliahan dan mengaktualisasikan keahlian tersebut pada pekerjaan mereka.

Berdasarkan hasil penelitian ini yang berada pada kategori sesuai tentu ini meningkatkan citra jurusan Manajemen Pendidikan. (Kellermann danSagmeister, 2000:34)menyatakan bahwa dalam dunia kerja ini pengangguran terus bertambahsetiaptahun, khususnya pengangguran dari lulusan perguruan tinggi. Oleh karena itu, para calon sarjana diwajibkan untuk lebih kreatif, inovatif, memiliki kompetensi, keterampilan kerja, dan kepribadian yang baik. Hal ini karena, lowongan yang tersedia sebenarnya yang akan menjadi kendala utama untuk seorang sarjana dalam mendapatkan pekerjaan adalah kesiapan mereka untuk bekerja. 
Dari hasil penelitian ini masih memerlukan evaluasi pada beberapa indikator yang ada guna untuk perbaikan dan pemantapan profesionalisme alumni Manajemen Pendidikan dalam dunia pekerjaan. Contohnya seperti pemantapan penguasaan komputer dan berbahasa Inggris karena pengetahuan tersebut yang sering diterapkan pada dunia pekerjaan. Selain itu, alumni dapat mengembangkan pengetahuannya dengan mengikuti pelatihan- pelatihan yang dilaksanakan noleh instansi mereka tersendiri.

3. Partisipasi Alumni dalam Mendukung KemajuanProgram Studi

Berkaitan dengan partisipasi alumni dalam mendukung kemajuan program studi, dapat diketahui bahwa indikator ini berada pada kategori cukup sesuai dengan presentase rata- rata yaitu $77.88 \%$. Hasil ini mengindikasikan bahwa pada indikator ini masih perlu adanya perbaikan dan peningkatan, baik yang dilakukan oleh pihak jurusan maupun mahasiswa atau alumni. Alumni memiliki peran yang sangat penting dalam mendukung kemajuan program studi. Menurut (Sahlan, 2012:262) melalui studi ini aumni bisa berperan sebagai control evaluasiuntukkemajuan sebuah perguruan tinggi, sehingga menghasilkan feedback untuk perbaikan proses perkuliahan, kurikulum, muatan mata kuliah, bahkan terhadap kualitasdosen.

Berdasarkan hasil penelitian diatas pada indikator ini bahwa ada beberapa faktoryangmempengaruhihaltersebut bisa terjadi, yang pertama tidak semua alumni berpartisipasi dalam kemajuan program studi, baik dalam kegiatan akademik dan non akademik, hanya saja ada beberapa alumni yang sudah terbiasa atau bekerja dilingkungan jurusan Manajemen Pendidikan ataudi Fakultas Ilmu Pendididkan saja yang sering berpartisipasi dalam kegiatan yang sering dilakukan oleh program studi. Kedua adalah ada beberapa alumni yang kurang merasa puas dengan sarana dan prasarana yang disediakan oleh jurusan, sehingga dapat menghambat proses pembelajaran yang dilakukan pada lingkungan jurusan Manajemen Pendidikan. (H.A.R. Tilaar, 2009:287) mengungkapkan partisipasi adalah sebagai bagian dari keinginan untuk mengembangkan demokrasi melalui proses desentralisasi dimana diupayakan antara lain perlunya perencanaan dari bawah (button-up) dengan melibatkan masyarakat dalam proses perencanaan dan pembangunan masyarakatnya.

Oleh karena itu, partisipasi alumni sangat diperlukan dalam upaya memperbaiki dan meningkatkan kualitasjurusan.Solusi dari permasalahan yang terjadi adalah memperbaiki hubungan antara dosen atau tenaga pendidik dengan alumni manajemen pendidikan. Ketika pihak jurusan dengan alumni mempunyai transparansi dan ingin memperbaiki citra manajemen pendidikanmakapermasalahan apapun itu bisa diatasi bersama. Contohnya ketika 
ada masukan dari alumni yang bertujuan untuk meningkatkan kualitas jurusan, pihak jurusan harus tanggap dan menerima masukan terebut sehingganya pemanfaatan alumni dalam meningkatkan kemajuan program studi bisa berjalan dengan baik dan sesuai dengan prosedur pelaksanaannya berupa penggalian lebih lanjut terhadap informasi lulusan. Selain itu, diperlukan komunikasi yang baik antara dosen dan alumni untukberbagi informasi tentang lapangan pekerjaan yang sesuai dengan latar belakang jurusan ManajemenPendidikan.

\section{SIMPULAN}

Berdasarkan hasil penelititan dan pembahasan yang telah dilakukan peneliti yang mengkaji tentang Analisis Daya Saing Lulusan Manajemen Pendidikan Fakultas Ilmu Pendidikan Universitas Negeri Gorontalo, maka dapat disimpulkan formasi kerja alumni berada pada kategori Cukup Tersedia. Ini disebabkan karena tidak semua alumni memiliki pekerjaan dan alumni masih kesulitan dalam mencari pekerjaan, kurangnya kemauan dari alumni untuk berusaha mendapatkan pekerjaan yang sesuai, dan kurangnya keterampilan alumni sehingga kalah bersaing dengan laumni dari jurusan lain. Kesesuaian bidang pekerjaan dengan keahlian berada pada kategori Sesuai, dikarenakan sebagian besar alumni bekerja sesuai dengan keahlian. Dari hasil tersebut, tentu ini meningkatkan citra jurusan Manajemen Pendidikan. Akan tetapi pencapaian tersebut masi memerlukan evaluasi pada beberapa indikator yang ada guna untuk perbaikan dan pemantapan profesionalisme alumni Manajemen Pendidikan dalam dunia pekerjaan. Partisipasi alumni dalam mendukung kemajuan program studi beradapadakategori Cukup Sesuai. Ini dikarenakan hanya beberapa alumni saja yang sering berpartisipasi pada kegiatan yang dilakukan oleh program studi dan ada beberapa alumni yang kurang merasa puas dengan tersedianya sarana dan prasarana penunjang pembelajaran pada jurusan manajemen pendidikan.

\section{REFERENSI}

Arwildayanto, 2012. Career Development Center Universitas Negeri Gorontalo, Gorontalo: Universitas Negeri Gorontalo.

Arwildayanto. 2013. Manajemen Sumber Daya ManusiaPerguruan Tinggi. Alfabeta. Bandung.

Arwildayanto, 2016. Pengembangan Budaya Kerja Champion dalam Pelaksanaan Tugas Pokok dan Fungsi Dosen Serta Pegawai di Fakultas Ilmu Pendidikan Universitas Negeri Gorontalo. Jurnal Manajemen 20(2):207-227.

Djuwariyah. 2008. Peningkatan Kualitas Sumber Daya Manusia melalui Pendidikan Islam. Jurnal Pendidikan Islam. Vol.1. No.1. 
Hamid, S. E. 2011. Membangun Daya Saing Institusi Pendidikan Berbasis Kompetensi Dasar Organisasi.

Hasyibuan, Malayu S. P. 2008. Manajemen Sumber Daya Manusia, BPFE. Yogyakarta.

H.A.R. Tilaar. 2009. Kekuasaan Pendidikan: KajianManajemen Pendidikan Nasional Dalam Pusaran Kekuasaan. Jakarta: Rineka Cipta.

Karnan, dkk. 2018. Pengisian Basis Data Alumni Program Studi Pendidikan Biologi FKIP Universitas Mataram. Jurnal Pendidikan dan Pengabdian Masyarakat. 2(1).

Kellermann, P dan Sagmeister, G. Higher Education And Graduate Employment In Austria. European Journal Of Education 35(2).

Robbins, Stephen P. Judge,TimothyA. 2013. PerilakuOrganisasi.Jakarta: Salemba Empat.

Sahlan, M. 2012. Profil Pilihan Karir Alumni Fakultas Dakwah UIN Sunan Kalijaga. Jurnal Dakwah.http://ejournal.uin-suka.ac.id/dakwah/jurnaldakwah/article/view/392/362.

Sedarmayanti, 2001. Sumber Daya Manusia, Bandung, PT. Refika Aditama

Siagian, S. 2008. Manajemen Sumber Daya Manusia. Bumi Aksara. Jakarta.

Sugiyah. 2010. Partisipasi Dalam Penyelenggaraan Rintisan. Yayasan SAF. Yogyakarta.

Sumihardjo. T. 2008. Daya Saing Berbasis Potensi Daerah. Puskomedia. Bandung.

Tampubolon. D. 2001. PerguruanTinggi Bermutu Paradigma Baru Manajemen PendidikanTinggi Menghadapi Tantangan Abad ke-21. PT Gramedia Pustaka Utama. Jakarta 